\title{
Miten autenttisuus ilmenee johtajien eettisessä päätöksenteossa?
}

\begin{abstract}
Abstrakti
Autenttinen johtajuus on itsensä tuntemiseen pohjautuva positiivinen johtajuuden muoto, jossa yksilö pyrkii toimimaan siten, että hän on aito ja rehellinen itselleen. Autenttisessa päätöksenteossa taas korostuvat eettisyys ja omien arvojen mukainen toiminta. Tässä tutkimuksessa selvitettiin, miten autenttinen johtajuus ilmenee esimiesten kohtaamissa eettisissä ristiriitatilanteissa ja miten tilanteiden ratkaisuissa näkyy autenttisen päätöksentekoprosessin vaiheita. Tutkittavat esimiehet $(n=25)$ työskentelivät sekä yksityisissä että julkisissa organisaatioissa, eri johtotasoilla ja eri toimialoilla. Puolistrukturoiduilla haastatteluilla kerättyä aineistoa analysoitiin teoriaohjaavan sisällönanalyysin avulla. Tulokset osoittivat, että autenttisen johtajuuden osa-alueet (itsetietoisuus, läpinäkyvyys, tasapuolinen tiedonkäsittely, sisäistetty moraali) ja autenttisen päätöksentekoprosessin vaiheet (eettisen ristiriidan tunnistaminen, vaihtoehtojen läpinäkyvä arviointi, aikomus toimia autenttisesti) olivat tunnistettavissa eettisessä päätöksenteossa. Kuitenkin vain alle puolet esimiehistä päätyi käytännössä omien arvojensa mukaiseen toimintaan. Erot aikomusten siirtymisessä toimintaan liittyivät yksilön ominaisuuksiin sekä ympäristön olosuhteisiin. Autenttisuutta johtajien eettisessä päätöksenteossa näyttääkin lisäävän se, että esimiehen yksilölliset ominaisuudet (esim. työkokemus ja reflektiokyky) ja työpaikan olosuhteet (esim. sosiaaliset suhteet) tukevat esimiehen vapautta, kykenevyyttä ja rohkeutta toimia omien arvojensa mukaisesti.
\end{abstract}

\section{Johdanto}

Yritysjohdon epäeettinen toiminta (esimerkiksi sisäpiirikaupat, petokset tai lahjonta) ja tästä seuranneet johtajien irtisanomiset ovat maailmanlaajuisesti lisääntyneet viime vuosien aikana (Karlsson ym. 2017). Myös Suomessa yritysmaailmassa paljastuneet epäkohdat, kuten Postin toimitusjohtajan palkkaskandaali (Helsingin Sanomat 1.9.2019), ovat lisänneet ihmisten epäluottamusta johtajia kohtaan ja lisänneet huolta johtajuuden nykytilasta. Tarve uudenlaisille johtajille on lisännyt kiinnostusta autenttiseen johtamiseen: johtajiin, jotka tuntevat itsensä, tuntevat aitoa intohimoa johtamiseen ja pitävät työyhteisön toimintaa ja hyvinvointia omaa asemaansa tärkeämpänä (Avolio \& Gardner 2005; George 2003). He johtavat merkityksellä, toivolla ja optimismilla, pohjautuen sisäistettyihin moraalisiin arvoihin ja eettisiin toimintatapoihin (May ym. 2003; Walumbwa ym. 2008).

Autenttinen johtajuus tarjoaakin yhden positiivisen näkökulman tulevaisuuden johtami- 
selle. Tästä huolimatta myös autenttiset johtajat joutuvat kohtaamaan työelämän moniulotteiset haasteet ja odotukset, jotka synnyttävät usein oikean ja väärän kysymyksiä eli eettisiä ristiriitoja. Näissä tilanteissa paras ratkaisu ei ole yksiselitteinen, ja johtajan päätöksillä voi olla merkittäviä seurauksia hyvässä tai pahassa koko organisaatiolle, sen henkilöstölle tai muille sidosryhmille (Messick \& Bazerman 1996). Autenttinen johtajuus voi kuitenkin tarjota paremman lähestymistavan eettisempien ratkaisujen saavuttamiselle verrattuna markkinajohtoiseen ja hierarkkiseen johtajuusmalliin, sillä autenttisuuteen kuuluu keskeisenä osana oikeudenmukainen ja moraalisesti vastuullinen toiminta verrattuna voittoa tavoittelevaan tai valtaa käyttävään johtajuuteen (Cranstono ym. 2006; Desmet ym. 2015). Aiheesta ei kuitenkaan ole olemassa empiiristä näyttöä. Tämän laadullisen tutkimuksen tarkoituksena onkin selvittää, kuinka esimiesasemassa toimivat henkilöt kuvaavat omassa työssään tapahtuneita eettisiä ristiriitatilanteita ja millä tavoilla autenttisuus näkyy näissä kuvauksissa. Tutkimuksemme tarjoaa uutta tietoa siitä, miten autenttinen johtajuus ja päätöksenteko ilmenevät näissä aidoissa työtilanteissa. Tätä tietoa voidaan hyödyntää johtajien eettisyyden ja autenttisuuden tukemisessa.

\section{Autenttinen johtajuus ja autenttinen päätöksenteko eettisissä ristiriitatilanteissa}

Autenttinen johtajuus pohjautuu positiiviseen psykologiaan (Seligman \& Csikszentmihalyi 2000) sekä positiiviseen organisaatiokäyttäytymiseen (Luthans 2002). Autenttinen johtaja tuntee hyvin itsensä, omat ajatuksensa ja periaatteensa ja toimii aidosti näiden mukaisella tavalla (Avolio ym. 2004; George 2003). Autenttinen johtajuus on ollut tutkijoiden kasvavan kiinnostuksen kohteena, mutta sitä on myös kritisoitu. Keskeisin kritiikki on kohdistunut autenttisen johtamisen käsitteeseen, jolle on olemassa useita erilaisia määritelmiä. Ne sisäl- tävät elementtejä johtajan ominaisuuksista, luonteenpiirteistä ja käyttäytymisestä, mikä tekee ilmiöstä epävakaan ja vaikeasti mitattavan (Cooper ym. 2005; Gardner ym. 2011). Lisäksi autenttisen johtamisen erillisyyttä muista positiivisen johtamisen käsitteistä (kuten transformationaalinen tai palveleva johtaminen; Dinh ym. 2014) on kyseenalaistettu. Kasvavan tutkimusnäytön myötä on kuitenkin voitu todeta, että autenttinen johtajuus tavoittaa muista käsitteistä erotettavan ja ainutlaatuisen ilmiön, jonka keskiössä ovat johtajan itsetuntemus ja sen kanssa johdonmukainen moraalinen toiminta (ks. katsaus Lemoine ym. 2019).

Autenttisen johtajuuden käytetyin määritelmä sisältää neljä osatekijää, jotka edistävät johtajien ja heidän alaistensa keskinäistä vuorovaikutusta ja henkilökohtaista kehitystä (Walumbwa ym. 2008; ks. myös Kinnunen ym. 2013). Itsetietoisuus (engl. self-awareness) tarkoittaa johtajan oman toiminnan, vahvuuksien ja heikkouksien tunnistamista ja halua kehittyä. Läpinäkyvyys (engl. relational transparency) tarkoittaa avointa tiedon jakamista tilanteelle sopivalla tavalla: asioiden suoraa käsittelyä, kykyä myöntää virheet sekä paljastaa omat todelliset ajatukset ja tunteet muille tavalla, joka edistää jaettua luottamusta. Tasapuolinen tiedonkäsittely (engl. balanced processing of information) näkyy kykynä analysoida objektiivisesti tilanteeseen liittyvää oleellista tietoa ennen päätöksentekoa sekä avoimuutena ottaa vastaan palautetta, kuunnella, ymmärtää ja huomioida eriäviä mielipiteitä. Sisäistetty moraali (engl. internalized moral perspective) viittaa johtajan moraaliseen itsesäätelyyn eli ulkoisista paineista tai tilannetekijöistä riippumatta tapahtuvaan omien arvojen mukaiseen eettiseen toimintaan.

Tarkastelemme tässä tutkimuksessa autenttista johtajuutta nimenomaan eettisten haasteiden kontekstissa. Eettiset haasteet eli dilemmat ovat ristiriitatilanteita, joissa ei ole olemassa yhtä oikeaa periaatetta, jonka pohjalta tehdä ratkaisuja. Sen sijaan päätös on tehtävä erilaisten kilpailevien periaat- 
teiden, arvojen, uskomusten ja ihanteiden välillä (Cranston ym. 2006). Johtajan kohtaamia eettisiä haasteita voivat olla esimerkiksi työyhteisössä ilmenevien riitojen sovittelu sekä henkilöstövalinnat tai irtisanomiset, joita kuvaa epävarmuus siitä, mikä tarjolla olevista ratkaisuvaihtoehdoista olisi oikea tai väärä. Tällaisissa tilanteissa eettistä toimintaa kuvaa vastuullisuus, toisin sanoen hyvän ja oikean toteutuminen, jota on johtajuuden tutkimuksessa lähestytty esimerkiksi palvelevan johtamisen (Greenleaf 1977) ja eettisen johtajuuden (Brown \& Treviño 2006) käsitteiden ja teorioiden avulla. Viimeaikaiset tutkimukset esimiesten tavoista ratkaista työelämän ristiriitatilanteita ovatkin tarjonneet viitteitä eettisen ja positiivisen johtajuuden merkityksestä päätöksenteossa suomalaisissa organisaatioissa (mm. Hiekkataipale \& Lämsä 2017; Salmi ym. 2014).

Autenttinen johtajuus on erityisen keskeinen ilmiö eettisten ristiriitojen näkökulmasta, sillä siinä moraalisuus yhdistyy esimiehen muihin positiivisin ominaisuuksiin: vahvaan itsetuntemukseen, läpinäkyvyyteen ja tasapuolisuuteen. Vaikka eettiset ongelmatilanteet ovat johtajille monella tapaa haastavia ja jopa kuormittavia (Huhtala ym. 2010), ongelmien ratkaiseminen on tärkeä osa johtajana toimimista. Tutkimukset ovat kuitenkin osoittaneet hyvien eettisten aikomusten olevan vain heikosti yhteydessä todelliseen eettiseen toimintaan (mm. Blasi 1980). Tästä syystä autenttisuus tarjoaa tärkeän näkökulman siihen, miten johtaja lopulta käytännön tasolla toimii: onko hänellä halua ja rohkeutta toteuttaa eettisiä ja moraalisia päätöksiä?

Toinen tutkimuksemme keskeinen viitekehys onkin autenttisen päätöksenteon prosessimalli (May ym. 2003). Mallissa on huomioitu sekä autenttisen johtajuuden moraalinen ulottuvuus että päätöksenteon eri vaiheet: eettisen ristiriidan tunnistaminen, kaikkien vaihtoehtojen läpinäkyvä arviointi sekä aikomus ja kyky toimia autenttisesti, sisäistettyjen moraaliarvojen mukaan. Näin ollen se tarjoaa teoreettisen lähtökohdan, jonka avulla autent- tisen johtajuuden ilmenemistä voidaan tarkastella käytännön tasolla: miten johtaja lähestyy, arvioi ja ratkaisee kohtaamiaan eettisiä haasteita.

Autenttinen päätöksentekoprosessi käynnistyy eettisen ristiriidan tunnistamisesta (Barnett \& Valentine 2004). Eettisen ristiriidan tunnistamiseen liittyy olennaisesti johtajan moraalinen kyvykkyys, joka on sitä suurempaa, mitä tietoisempi johtaja on omasta roolistaan eettisenä roolimallina, mitä paremmin hän kykenee arvioimaan eettisiä ristiriitatilanteita eri näkökulmista ja mitä enemmän kokemusta hänellä on tällaisista ristiriitatilanteista ja niiden ratkaisemisesta (May ym. 2003).

Kun autenttinen johtaja on tunnistanut tilanteen eettisen ulottuvuuden, hän pyrkii vertailemaan erilaisia ratkaisuvaihtoehtoja ja niistä eri osapuolille koituvia seurauksia mahdollisimman avoimesti, ajatusprosessiaan ongelmatilanteen osapuolilta peittelemättä. May ja kollegat (2003) korostavat, että autenttisen johtajan toiminnassa päätösten taustalla vaikuttavat moraaliset periaatteet. Välittömien seurausten (esimerkiksi asianosaisille aiheutuvat hyödyt tai haitat) lisäksi autenttinen johtaja ottaa huomioon erilaiset sitoumukset ja velvollisuudet, joita hänellä on eri ristiriidan osapuolia kohtaan, osapuolien oikeudet ja lopullisen päätöksen reiluuden ja oikeudenmukaisuuden (emt.).

Tarkasteltuaan tarjolla olevia vaihtoehtoja autenttinen johtaja päätyy ratkaisuun, joka on hänen arvioidensa mukaan kaikkien osapuolien kannalta paras mahdollinen (May ym. 2003). Pelkän eettisen arviointikyvyn on kuitenkin havaittu liittyvän vain heikosti varsinaiseen eettiseen toimintaan (Blasi 1980; Treviño \& Youngblood 1990). Näin ollen autenttisen päätöksentekoprosessin osalta olennaista on paitsi päätyminen sisäistettyjen moraaliarvojen mukaiseen ratkaisuun, myös johtajan pyrkimys ja halu toteuttaa tämä ratkaisu käytännössä. Autenttisessa päätöksentekoprosessissa oletuksena on, että johtaja on ristiriitatilanteen sattuessa vapaa toimimaan haluamallaan 
tavalla, ja että hänen tavoitteenaan on pyrkiä arvojensa ja uskomustensa mukaiseen ratkaisuun. Toimiiko johtaja lopulta autenttisesti vai ei riippuu kuitenkin olennaisesti johtajan moraalisesta rohkeudesta (May ym. 2003): kyvystä sitoutua omiin moraalisiin periaatteisiin jopa henkilökohtaisen riskin uhalla (Hannah ym. 2011; Sekerka \& Bagozzi 2007).

Yllä kuvattu päätöksentekoprosessi yhdistyy johtajan autenttisuuteen erityisesti sisäistetyn moraalin ulottuvuuden kautta (Avolio ym. 2004). May ja kollegat (2003) argumentoivatkin, että autenttiset johtajat tunnistavat muita johtajia paremmin työpaikalla tapahtuvia eettisiä ristiriitatilanteita ja ovat myös kykenevämpiä arvioimaan näiden tilanteiden moraalista intensiteettiä heidän korkeamman moraalisen kyvykkyytensä vuoksi. Näin ollen autenttinen johtaja havaitsee todennäköisemmin työhönsä sisältyvät eettiset ulottuvuudet. Hän voi myös kokea niistä suurta vastuuta sekä voimakasta halua toimia oikein. Jos tilanne ei sitä salli tai odotukset oikealle toiminnalle ovat ristiriitaisia, autenttinen johtaja voi kokea tilanteet erityisen haastavina. Näin ollen voidaan olettaa eettisten ristiriitatilanteiden olevan erityisen otollisia tilanteita tarkastella autenttisuutta sekä johtajan ominaisuutena että päätöksenteon ulottuvuutena. Tästä huolimatta aiheesta ei ole olemassa aiempaa empiiristä tutkimusnäyttöä (Cianci ym. 2014; Lemoine ym. 2019). Emme siis tiedä, toimivatko autenttiset johtajat todella arvojensa mukaan myös eettisesti haastavissa ongelmatilanteissa, ovatko kaikki autenttisuuden ulottuvuudet yhtä keskeisiä näissä päätöksissä tai eteneekö päätöksentekoprosessi Mayn ja kollegojen (2003) ehdottaman mallin mukaisesti. Tutkimuksemme tuokin uutta tietoa siitä, miten autenttisuus ilmenee erityisesti eettisissä ongelmanratkaisutilanteissa, ja miten aidot työssä tapahtuneet tilanteet (verrattuna esimerkiksi kokeellisiin asetelmiin tai kuvitteellisiin vinjetteihin perustuviin tutkimuksiin, joissa vastaajalle esitetään tarina hypoteettisesta eettisestä ongelmasta) sekä niihin liittyvät haasteet ja kontekstuaaliset tekijät mah- dollisesti vaikuttavat päätöksentekoon ja käytännön tasolla tapahtuvaan toimintaan. Kuten Sinkkonen ja Laulainen $(2010,240)$ ovat todenneet, johtajan eettisyys punnitaan hänen rohkeudessaan toimia eettisten periaatteidensa mukaisesti käytännön tasolla.

Tutkimuksemme tavoitteena on selvittää, millä tavoin autenttisen johtajuuden osa-alueet (itsetietoisuus, läpinäkyvyys, tasapuolinen tiedonkäsittely, sisäistetty moraali) esiintyvät esimiesten eettisiä ristiriitatilanteita kuvaavissa kertomuksissa. Lisäksi tutkimme, miten esimiehet kuvaavat päätöksentekoprosessinsa eri vaiheita (eettisen haasteen tunnistaminen, arviointi ja toiminta) erityisesti autenttisuuden näkökulmasta. Lopuksi tarkastelemme, miten autenttinen johtajuus ja autenttinen päätöksenteko kytkeytyvät toisiinsa eettisen ongelmanratkaisun kontekstissa. Tutkimuksemme pyrkii siis lisäämään ymmärrystä autenttisuudesta moniulotteisena ilmiönä johtajien työssä ja samalla tuottamaan tietoa, jota voidaan hyödyntää johtajien tukemisessa erityisesti eettisiin kysymyksiin liittyvässä päätöksenteossa.

\section{Aineisto ja menetelmät}

\section{Tutkittavat ja aineiston keruu}

Tutkimuksen aineisto on osa Suomen Akatemian rahoittamaa Moraalinen työidentiteetti -hanketta (294428), joka toteutettiin vuosina 2016-2019. Tutkittavat edustivat kahta erilaista perusjoukkoa: yhtä julkisen sektorin organisaatiota, jossa oli edustettuna laaja kirjo erilaisia palvelualueita, sekä kokeneen liikkeenjohdon Executive MBA (EMBA) -koulutukseen osallistuneita johtajia. Jokaiselle julkisessa organisaatiossa esimiehen nimikkeellä toimineelle sekä kaikille vuonna 2017 EMBA-kurssille osallistuneille lähetettiin tutkimuksen yhteyshenkilöiden kautta sähköpostitse kutsukirje osallistua haastattelututkimukseen. Tutkimukseen osallistuneilta pyydettiin kirjallinen suostumus haastatteluiden nauhoittamiseen ja myöhem- 
pään tutkimuskäyttöön. Valmis aineisto anonymisoitiin muuttamalla tunnistamisen mahdollistavat tiedot ja sen käsittelyssä ja säilytyksessä noudatettiin tutkimuseettisiä ohjeita.

Tutkimukseen osallistui yhteensä 25 henkilöä, joista 12 oli miehiä ja 13 naisia. Haastateltavien keskimääräinen ikä oli 49 vuotta (36-65, kh = 8,5). Tutkimuksessa oli mukana sekä ylemmän että alemman tason esimiehiä monilta eri aloilta (mm. sosiaali- ja terveysala, kasvatus- ja koulutusala, liiketoiminta). He työskentelivät julkisella sektorilla $(n=19)$, yksityisellä sektorilla $(n=3)$ tai omistivat oman yrityksen ( $n=3)$ ja heidän työkokemuksensa alalla vaihteli yhdestä vuodesta 40 vuoteen $(\mathrm{ka}=9$, $\mathrm{kh}=9,4)$. Tämä heterogeeninen otos mahdollisti autenttisuuden tutkimisen eri-ikäisten, eri kokemustaustaisten ja eri tasolla toimivien esimiesten parissa. Sen avulla pystyimme selvittämään yksilöllisten tekijöiden yhteyksiä autenttisuuden ilmenemiseen, mutta myös tunnistamaan yhteneviä autenttisuuden muotoja, jotka olivat riippumattomia otoksen moninaisuudesta. Tämä parantaa tutkimuksen yleistettävyyttä.

Aineistonkeruumenetelmänä käytettiin puolistrukturoitua haastattelua, jonka tavoitteena oli saada mahdollisimman konkreettista tietoa esimiesten kokemista eettisistä ongelmatilanteista työssään sekä niissä tapahtuneesta päätöksenteosta. Haastatteluissa käytettiin kriittisten tapausten tekniikkaa (engl. Critical Incident Technique, CIT; Flanagan 1954), jonka avulla on mahdollista kerätä yksilöllisiä kokemuksia henkilökohtaisesti merkittävistä tapahtumista ja tietoa toiminnan lopputulokseen vaikuttaneista syistä. Tekniikan keskeinen etu on, että haastateltavat lähestyvät tutkimusaihetta konkreettisen, omassa työssä tapahtuneen tilanteen kautta, jolloin vastaukset eivät jää epämääräiselle tasolle (Lämsä ym. 2015). Siten se soveltuu hyvin kartoittamaan eettisiä ristiriitatilanteita, jotka yksilö on kokenut itselleen jollain tavalla tärkeiksi. Menetelmä lisää myös tutkimuksen yleistettävyyttä ja edustavuutta, sillä se takaa, että haastateltavilla on omakohtaista kokemusta tutkittavasta aiheesta. Haastattelurungon rakentamisessa hyödynnettiin lisäksi Weaverin (2006) teoreettista mallia, jonka pohjalta kysymyksiksi poimittiin organisaatioissa tapahtuvan moraalisen toiminnan kannalta keskeisiä teemoja: Miksi tilanne oli eettisesti ongelmallinen? Millaisissa olosuhteissa tilanne syntyi? Mitä esimies tarkkaan ottaen teki ratkaistakseen ongelman? Mikä vaikutus eri tahoilla (esim. ylin johto, kollegat, alaiset) oli päätöksentekoon? Onko esimies toiminut muissa eettisesti ongelmallisissa tilanteissa eri tavoin ja jos on, miten?

Ennen haastatteluun saapumista tutkittavat saivat kirjeen, jossa heitä ohjeistettiin miettimään yhtä tai useampaa työssä kohtaamaansa eettistä ongelmaa sekä kerrottiin etukäteen haastattelussa esitettävät kysymykset. Ohjeistuksen tarkoituksena oli auttaa tutkimushenkilöitä virittäytymään eettisistä teemoista puhumiseen ja haastattelurungon läpinäkyvyyden avulla madaltaa kynnystä joskus vaikeidenkin eettisten asioiden puheeksi ottamiseen. Haastattelut kestivät 23 minuutista yli tuntiin ( $\mathrm{ka}=42 \mathrm{~min}$ ). Haastattelut nauhoitettiin ja litteroitiin sanatarkasti. Aineistonkeruu lopetettiin haastattelut toteuttaneen tutkijan arvioinnin perusteella sen jälkeen, kun aineiston katsottiin saavuttaneen kyllääntymisen eli saturaation: haastatteluissa ei enää noussut esille tutkimuskysymysten kannalta uutta olennaista tietoa.

\section{Tutkimusmenetelmät ja analyysi}

Analyysi aloitettiin teemoittelulla, jonka avulla aineistoa pelkistettiin ja siitä etsittiin tutkimuskysymysten kannalta olennaisia kohtia, jotka pyrittiin erottamaan muusta aineistosta (Eskola \& Suoranta 1998; Tuomi \& Sarajärvi 2018). Tämän jälkeen käytettiin teoriaohjaavaa sisällönanalyysiä, jossa vuorottelevat sekä aineistolähtöisyys että valmiit teoreettiset mallit. Vaikka aiempi tutkimustieto ja ymmärrys aiheesta ohjasivat analyysia, tavoitteena ei ollut ainoastaan testata tiettyä teoriaa, vaan 
pyrkimyksenä oli herättää uusia ajatuksia tutkittavasta aiheesta (Tuomi \& Sarajärvi 2018). Tutkimuksessa käytettiin tutkijatriangulaatiota. Tutkimuksen suunnittelusta ja haastatteluiden toteutuksesta vastasi kolmas kirjoittaja. Tutkimuksen ensimmäinen ja toinen kirjoittaja lukivat koko aineiston itsenäisesti läpi useita kertoja ja merkitsivät ylös omia tulkintojaan näistä eri sisältöluokista, joista he myöhemmin keskustelivat kolmannen kirjoittajan kanssa.

Analyysin ensimmäisessä vaiheessa aineisto luettiin läpi ilman ennakko-oletuksia, mutta pitämällä mielessä positiivisen psykologian ja positiivisen johtajuuden näkökulmat. Tutkimuskirjallisuuteen tutustuttiin samanaikaisesti aineiston lukemisen kanssa, jolloin esiin nousivat autenttisen johtajuuden käsite (Walumbwa ym. 2008) sekä teoria johtajien autenttisesta päätöksentekoprosessista (May ym. 2003), joilla havaittiin olevan yhteneväisyyksiä aineistoon. Analyysin toisessa vaiheessa aineistoa teemoiteltiin autenttisen johtajuuden ulottuvuuksien (itsetietoisuus, läpinäkyvyys ihmissuhteissa, sisäistetty moraali ja tasapainoinen tiedonkäsittely; Walumba ym. 2008) sekä autenttisen päätöksentekoprosessin vaiheiden (eettisen ristiriitatilanteen tunnistaminen, vaihtoehtojen läpinäkyvä arviointi, aikomus toimia autenttisesti; May ym. 2003) mukaisesti poimimalla kuvaavia tekstiotteita kunkin teeman alle. Samanaikaisesti tarkasteltiin aineistohavaintoja, jotka eivät sopineet näiden teoreettisten teemojen alle. Näiden aineistohavaintojen avulla pyrittiin saavuttamaan uudenlaista tietoa autenttisesta johtajuudesta erityisesti eettisen päätöksenteon kontekstissa. Kaikkien aineistohavaintojen merkityksiä johtajien autenttisuudelle ja heidän päätöksenteolleen pohdittiin vuorotellen kirjallisuuden sekä aineiston lukemisen välillä, ja näitä kahta keskeistä käsitettä tarkasteltiin suhteessa toisiinsa. Lopuksi kunkin esimiehen kohdalla arvioitiin, päätyikö tämä arvojensa mukaiseen ratkaisuun ja ratkaisun pohjalta arvojensa mukaiseen toimintaan, eli toisin sanoen toteutuiko autenttinen päätöksentekoprosessi loppuun asti.

\section{Autenttisen johtajuuden osa-alueet johtajien kertomuksissa}

Kaikki autenttisen johtajuuden osa-alueet (itsetietoisuus, läpinäkyvyys, tasapuolinen tiedonkäsittely, sisäistetty moraali) olivat tunnistettavissa aineistosta. Esimiesten välillä oli kuitenkin paljon vaihtelua siinä, kuinka monipuolisesti he kertomuksissaan kuvailivat kunkin osa-alueen mukaista toimintaa. Esimiesten keskinäinen vertailu osoitti, että tutkittavien joukossa oli niitä, joiden puheesta ei noussut esiin yhtäkään autenttisen johtajuuden osa-aluetta, sekä niitä, jotka kuvailivat yhden, kahden, kolmen tai jopa kaikkien neljän osa-alueen mukaista toimintaa. Käsittelemme seuraavaksi kutakin autenttisen johtajuuden osa-aluetta erikseen. Käytetyissä sitaateissa olemme kuvanneet haastateltavan sukupuolen, iän sekä työkokemuksen pituuden. Osa johtajista ilmoitti työsuhteen pituuden nykyisessä tehtävässään, osa koko kertyneen työkokemuksensa.

\section{Itsetietoisuus}

Esimiesten itsetietoisuus ilmeni aineistossa hyvin moninaisesti muun muassa oman toiminnan reflektoimisen, itsekriittisyyden, heikkouksien ja vahvuuksien tunnistamisen sekä niiden pohtimisen kautta:

Mun ongelma on juuri se, et mä oon ehkä liian empaattinen ja liian kiltti. Se on aika luontasta, että mä katon asioita aika monesta eri näkökulmasta, että on tilanteita, että pitäis katsoa vaan siitä jyrkän esimiesnäkökulmasta, mutta et sitten kun tuntee ne ihmiset ja ymmärtää ne taustat ja tietää, mikä tän henkilön kohdalla on johtanut siihen tilanteeseen, niin se on se, mikä tuo mulle niitä ongelmia. (nainen, 56, työkokemusta alalta 10 vuotta)

Esimiehet, joilla oli runsaasti itsetietoisuutta heijastavaa puhetta, kuvasivat haastatteluissa paljon myös henkilökohtaista reflektiota omiin arvoihin ja toimintaan liittyen: 
Nii, mä kyl yritän ajatella, etten toimis kaavamaisesti. Et vaikka ne omat arvot ja eettiset lähtökohdat pitää olla kuitenkin siellä pohjana, mut sitten kun ongelmat ja tilanteet on vaihtuvia, nii siltä omalta arvopohjalta pitää pystyä soveltamaan ja toimimaan erilailla. Että ei voi toimia niin kuin kaavamaisesti. Et pitää osata elää hetkessä ja tehdä oikeenlaiset arviot siitä, niistä mitä keinoja esimerkiks käyttää, millä lailla toimii ja yrittää vaikuttaa asioihin. (mies, 57, työkokemusta alalta 27 vuotta)

Esimiehillä, joilla itsetietoista puhetta ilmeni hyvin vähän tai ei ilmennyt lainkaan, havaittiin vähän myös muihin autenttisen johtamisen osa-alueisiin liittyviä ilmaisuja. Näiden esimiesten puheessa korostui sen sijaan konkreettisen tilanteen kuvailu, siihen liittyvien sääntöjen noudattaminen, tavoite- ja toimintakeskeisyys tai omien ajatusten ja johtopäätösten suoraviivaisuus, jopa yksipuolisuus.

\section{Läpinäkyvyys}

Esimiehet kuvasivat pyrkimystään toimia ongelmatilanteissa läpinäkyvästi kertomalla, miten he olivat toteuttaneet avoimuutta työyhteisössään. Tällaisia esimerkkejä olivat ongelmien ja vaikeuksien rohkea ja avoin esille ottaminen, joko laajasti työyhteisössä tai pelkästään ongelmatilanteeseen liittyvien asianosaisten kanssa. He eivät piilotelleet asioita alaisiltaan vaan informoivat meneillään olevasta tilanteesta ja sen mahdollisista seurauksista rehellisesti ja avoimesti:

Mun mielestä se oli päivänselvää, että mä informoin koko työvuoroo siitä, että mitä on tapahtunu, miks on tapahtunu ja miten edetään. Koska se osaa närästää, jos ne lakastaan maton alle. Vaikka kukaan ei välttämättä sano sitä ääneen, nii se jää niinku pinnan alle, että perkele tuoki painelee villasella. Ja silloin kun asiasta puhutaan oikeilla nimill, ja ryhdikkäästi kerrotaan, mitä tässä nyt on tehty, kuka on sössiny ja mitä nyt tehdään, että tämä tilanne korjataan, nii se keskustelu loppu käytännössä siihen. (mies, 43, työkokemusta alalta 18 vuotta)

Näitä kuvauksia oli aineistossa muita autenttisuuden osa-alueita vähemmän. Esimiehille oli yleisempää kuvata eettisiin ongelmatilanteisiin liittyviä henkilökohtaisia tunteita, ajatuksia ja pohdintoja tilanteeseen sopivasta toiminnasta, mutta vain harvat kertoivat ilmaisseensa näitä avoimesti tilanteen eri osapuolille. Huomattavaa oli, että avoin ajatusten ja tunteiden jakaminen muille saattoi olla vähäistä myös niillä esimiehillä, jotka voitiin muiden osa-alueiden perusteella tunnistaa toiminnassaan hyvinkin autenttisuutta ilmentäviksi. Yksi syy liittyi ongelmatilanteiden arkaluontoisuuteen, jonka vuoksi esimiehet tietoisesti rajoittivat liiallista läpinäkyvyyttä:

No on tietysti semmoisia tilanteita esimiestyöhön liittyen vaikka, et ne koskee henkilösidonnaisia asioita, missä oon tehnyt ratkaisuja, joita ei voi kertoo omalle työyhteisölleen esimerkiks. Ne on itseasiassa aika raskaitakin loppupeleissä: et se näyttäytyy vaikka joku tilanne [alaisille], että esimies ei toimi, mutta sitte se toimiiki, mut se ei voi kertoo sitä muille. (nainen, 38, työkokemusta alalta 14 vuotta)

\section{Tasapuolinen tiedonkäsittely}

Esimiesten tasapuolinen tiedonkäsittely näkyi muun muassa asioiden pohtimisena monelta eri kannalta sekä pyrkimyksinä ottaa huomioon kaikkien osapuolien näkemykset ennen päätöksentekoa. Esimiehet pyrkivät kuulemaan eettisen ristiriidan asianosaisia, kuten omaa esimiestään, henkilöstöpäällikköä, juristia ja alaisiaan, ja pohtivat eri vaihtoehtojen seurauksia kunkin osapuolen kannalta tai laajemmin yhteiskunnallisesta näkökulmasta: 
Siis enemmän mä kuuntelen ihmisiä, etten tee päätöksiä niin hirveesti yksin. Että pyrin enemmän vielä kuuntelemaan, sit se on helpompi sanoo niitä asioita. Ja sit pyrin eri kantilta ajattelemaan, et en tee nopeesti niitä päätöksiä. (nainen, 48, työkokemusta alalta 26 vuotta)

Esimiehet kuvasivat vähemmän vaihtoehtoisten näkökulmien etsintää, mikäli heillä oli vain harvoja tai ei yhtäkään luotettua henkilöä omassa lähipiirissään. Esimerkiksi suhde omaan esimieheen tai läheiseen kollegaan saattoi olla ristiriitainen, jolloin neuvojen tai mielipiteiden saaminen oli hyvin hankalaa:

Mulla on yks, joka on periaatteessa mun kollega. -- Niin hän on siitä saakka, kun mä tulin taloon, kaikilla mahdollisilla tavoilla yrittänyt saada mut epäonnistumaan. Ja se ois ollu se henkilö, jonka kanssa... joka on samalla tasolla kuin minä. Niin mulla ei ois ollu minkään näköistä mahdollisuutta mennä hänelle kertoon tän tyyppisistä asioista -- hän on kuvitellu olevansa mun yläpuolella. Et mä jäin tos tilantees tosi yksin. (nainen, 42, työkokemusta kyseisessä tehtävässä 2 vuotta)

Yllä kuvatun sitaatin mukaisesti jotkut esimiehet kokivat jäävänsä täysin yksin päätöksenteossaan. Osa heistä ei kuvannut lainkaan pyrkimystä kartoittaa erilaisia näkemyksiä eettiseen dilemmaan liittyen. Osa yksin jäävistä esimiehistä taas kuvasi haluavansa harkita monipuolisesti eri näkökulmia päätöksenteossaan, mutta luotettavien vuorovaikutussuhteiden puuttuessa heillä ei ollut siihen mahdollisuutta.

\section{Sisäistetty moraali}

Sisäistettyä moraalia kuvasi esimiesten puhe siitä, miten eettisyys korostui heidän arvoissaan, ajatuksissaan ja toiminnassaan: haluna toimia oikein, omien arvojen rohkeana esille tuomisena sekä arvojen mukaan toimimisena. Useat esimiehistä nostivat keskeisimmiksi ar- voikseen oikeudenmukaisuuden ja tasapuolisuuden. Tärkeinä arvoina nousivat esille myös rehellisyys, suvaitsevaisuus, turvallisuus, ihmisarvo ja sen kunnioittaminen, ahkera työnteko, vastuullisuus sekä alaisten hyvinvointi. Esimiehet kuvasivat ymmärtävänsä oman vastuunsa ja velvollisuutensa. He myös kertoivat halusta toimia esimerkillisesti sekä uskalluksesta olla tarvittaessa muiden kanssa eri mieltä. Muutama esimies kertoi noudattavansa omia arvojaan, vaikka ne olisivat ylempää tulevien odotusten tai määräysten vastaisia:

Mä oon aatellu kolme yksinkertaista kysymystä: et onks tää turvallista on ensimmäinen kysymys. Ja sitten et onks tää oikein, ja siis tämmöinen eettinen kysymys, et onks tää oikein, ei et onks tää pykälien mukaista. Ja kolmantena, et onks se tasapuolista. Mä oon aatellu sen niin, et jos mä vastaan näihin kaikkiin myöntävästi ja toimin sen mukaan ja tulen siinä sivussa rikkoneeksi lakia tai pykälää tai asetusta, niin ei mua voida kauhean pahasti tuomita, koska mulla on ollu puhtaat tarkoitusperät. (mies, 42, työkokemusta kyseisessä tehtävässä 1 vuosi)

Nämä esimiehet noudattivat selkeää moraalista arvoperustaa, jonka pohjalta he kykenivät tekemään ratkaisuja ja päätöksiä ulkoapäin tulevien vaatimusten ristiriitaisuudesta huolimatta.

\section{Autenttinen päätöksentekoprosessi}

Autenttinen päätöksentekoprosessi ei näyttäytynyt aineistossa tietynlaiseen yksiselitteiseen tai yleisesti hyväksyttyyn loppuratkaisuun päätymisenä. Sen sijaan keskeistä oli eri vaiheiden ilmeneminen esimiehen kuvaamassa ajatteluprosessissa ja tämän pohjalta seurannut omien arvojen mukainen päätös. Autenttisen päätöksentekoprosessin vaiheiksi luokiteltiin Mayn ja kumppaneiden (2003) mallin mukaisesti eettisen ristiriidan tunnistaminen, vaihtoehtojen läpinäkyvä arviointi sekä aikomus toimia autenttisesti. Kaikki aineiston esimiehet tunnisti- 
vat tilanteessa läsnä olevan eettisen ristiriidan, mikä olikin odotettavissa, sillä osallistujia ohjeistettiin etukäteen miettimään eettisiä dilemmoja työssään. Tämän jälkeen esimiehet lähestyivät kuitenkin eettisiä ongelmia eri tavoin. Osa esimiehistä päätyi toimimaan joidenkin ulkoisten tekijöiden, kuten organisaation virallisen toimintamallin sanelemana, jolloin autenttinen päätöksentekoprosessi jäi toteutumatta. Eräs esimies kuvasi tällaista tilannetta seuraavasti:

No tämmönen johon oikeestaan mä en voi vaikuttaa millään lailla, niin meillä on välillä 90 päivää tämmönen maksuaika, mikä on sitte ehkä vähän - Suomen lakien kans$s a$, että jos vietäs niitä käräjille, niin ne luultavasti tulis lyhemmät maksuajat siitä. Että niin, se on ehkä omien arvojen vastaista se toiminta. Mutta en mä oikeestaan sille voi mitään tehdä - Se on firman toimintatapa. (mies, 42, työkokemusta kyseisessä tehtävässä 9 vuotta)

Useimmat kuitenkin siirtyivät päätöksentekoprosessin seuraavaan vaiheeseen: pohtimaan erilaisia ratkaisuvaihtoehtoja monista eri näkökulmista. Autenttisen päätöksenteon näkökulmasta tässä vaiheessa olennaista on läpinäkyvyys (May ym. 2003), ja osa esimiehistä pohtikin vaihtoehtoja avoimesti tilanteen eri osapuolten kanssa:

Siinä mä sitten otin ohjaksia käsiin, ja ihan tein semmoisen suunnitelman, että mä selkeästi nyt vietän aikaa siellä, perehdyn, käydään tiimissä yhdessä siellä sen työporukan kanssa asioita [läpi], ja sit mä tuun haastattelemaan kaikkia yksittäin. Että pureudutaan oikeesti siihen tilanteeseen, että mikä siellä on. Lähden muodostaan sitä kautta sitten itse sitä kuvaa. (nainen, 48, työkokemusta alalta 15 vuotta)

Osalla esimiehistä läpinäkyvyyden toteutuminen jäi selvästi vähäisemmäksi:
En mä tiiä - se päätöksenteko, sehän on helppoo, mä oon vähän mustavalkonen, se on kyllä tai ei. Useimmiten. Tai sit se on, et en minä tiedä ja sit se menee niinkun tämmöseen laatikkoon, että odottaa hieman. (mies, 36, työkokemusta kyseisessä tehtävässä 10 vuotta)

Autenttisen päätöksentekoprosessin viimeinen vaihe sisältää omien arvojen mukaisen päätöksen ja aikomuksen toimia sen mukaisesti. Aineiston esimiehistä kymmenen kertoi päätyneensä lopulta omien arvojensa mukaiseen ratkaisuun, jonka he olivat myös toteuttaneet käytännössä:

Mä päätin, että siihen [toisen työntekijän epäasialliseen käytökseen] on pakko puuttua, koska henkilökunta voi huonosti. Mä en niiku kykene olemaan, et jos mä en [puutu] siihen, koska se on mun tehtävä puuttuu huonoon käytökseen. (nainen, 61, työkokemusta kyseisessä tehtävässä 10 vuotta)

Autenttisen päätöksentekoprosessin vaiheet eivät edenneet lineaarisesti esimiesten kertomuksissa, vaan niiden järjestys saattoi vaihdella tai eri vaiheet saattoivat esiintyä limittäin toistensa kanssa. Yksi esimerkki epälineaarisesta päätöksenteosta näkyi erityisen hyvin erään esimiehen toiminnassa. Hän päätyi aluksi ylimmän johdon käskyjen mukaan arvojensa vastaiseen toimintaan, mutta päätti pitkällä tähtäimellä vaikuttaa tilanteeseen niin, että pystyi saattamaan autenttisen päätöksentekoprosessin loppuun ja toimimaan arvojensa mukaan:

Kun mä olin jotakuinkin varma, omasta mielestäni, omien näkemysteni, tavoitteiden, arvojeni oikeellisuudesta nii sit mä päätin, että mä lähden vaikuttamaan kaikissa käytettävissä olevin keinoin sen [resurssien] leikkauspäätöksen kumoamiseksi pidemmällä aikavälillä. Mä tiesin, että mä en pysty vaikuttaa siihen, kun se päätös oli meiän organisaatios tehty demokraattisesti, kaikin puolin ok muodollisesti, nii mä en pysty siihen kovin lyhyellä aikavälillä vaikuttaa. Mutta uskoin mahdolli- 
suuksiini, et mä pystyn siihen pitkällä aikavälillä vaikuttaa. (mies, 57, työkokemusta kyseisessä tehtävästä 27 vuotta)

\section{Autenttisen johtajuuden ja päätöksenteon keskinäinen suhde}

Kun tarkastelimme autenttisuutta johtajuuden muotona ja osana eettisen päätöksenteon prosessia, selkeimmät erot esimiesten välillä näkyivät sisäistetyssä moraalissa ja sen mukaisessa toiminnassa: kantoiko autenttinen päätös käytäntöön asti vai ei. Lähes jokainen johtaja toi esille keskeisimpiä arvojaan, mutta läheskään kaikki eivät toimineet näiden arvojen mukaan, sillä yli puolella esimiehistä autenttinen päätöksentekoprosessi jäi ajattelun ja aikeiden tasolle. Osa esimiehistä kuitenkin kuvasi selkeästi toimineensa omien vahvasti sisäistettyjen moraaliarvojensa mukaan. Heillä eettisen tilanteen ongelmanratkaisussa näkyivät kaikki autenttista johtajuutta määrittelevät tekijät (itsetietoisuus, läpinäkyvyys, tasapuolinen tiedonkäsittely ja sisäistetyt moraaliarvot):

Yksi semmoinen, joka mulla on ollut, ihan semmoinen varmaan perusarvo aina, niin on tavallaan se oikeudenmukaisuuden arvo. Mun mielestä se on ihan perusta kaikelle tekemiselle, ihan siis muussakin elämässä, mutta erityisesti, kun sä oot esimiestehtävässä. Että sitä kautta, että sä oot oikeudenmukainen ja sä perustelet asioita ihmisille, niin ihmiset monta kertaa semmoisia negatiivisiakin asioita ja päätöksiä, koska sähän joudut esimiehenä niitäkin tekeen paljonkin. Ihmisethän hyväksyy ne, kun he ymmärtää, että hei, että tässä on ihan selkee logiikka, että sä oot tietyllä tavalla johdonmukainen sun tekemisissä ja sä teet nää päätökset siitä syystä, että täällä on tämmöisii jotain taloudellisii, joskus joudutaan vähentään resursseja ja muuta. Mutta kun ne on tavallaan perusteltu ja sit ne koskee, ne samat säännöt koskee kaikkia. (nainen, 48, työkokemusta kyseisessä tehtävästä 5 vuotta)
Tietenkin myös kokemus siitä, kun on kaikki tullu siinä tasavertaisesti ennen kaikkea kohdatuksi, niin se auttaa sen tilanteen selviämistä ja ei tuu semmosta tunnetta kenellekään, että ois toimittu epäoikeudenmukaisesti tai että minun ääntäni ei olisi tässä kuultu. Niin kyllähän siihen pitää pyrkiä. Vaikka se viekin aikaa enemmän, mutta lopputulos on sitten pidemmällä aikavälillä parempi. Et kyllä siellä arvot varmaan taustalla sitten mulla itellä on, ja sitten arvojen lisäksi se kokemus siitä, että kun toimii sillä tavalla, niin se kantaa sitten hyvää hedelmää. (mies, 56, työkokemusta alalta 30 vuotta)

Toisaalta osa esimiehistä kuvasi kohdanneensa esteitä, jotka olivat estäneet arvojen mukaisen toiminnan:

Yhteiskunnalliset päätökset on siellä taustalla vaikuttanut. Että onko ne ollut esimerkiksi mun arvovalintoja, niin ne ei oo ollu mun valintoja. Mä oon eri mieltä niistä. Mutta koska ne on linjattu... ne vaikuttaa meilläkin tällä hetkellä. Mä oon sitä yrittänyt porukoille selittää, mutta kyllä ne on täysin eri mieltä kaikista näistä taloudellisista linjoista, monista asioista. Mutta mitä ne vaikuttaa meille, niin mun pitää toteuttaa sitä. (mies, 53, työkokemusta alalta 20 vuotta)

Autenttiseen toimintaan liittyi olennaisesti moraalinen rohkeus. Se ilmeni haastatteluissa pelottomuutena uhmata lakeja tai säädöksiä sekä työpaikkaa koskevia linjauksia tai käskyjä ylemmältä johdolta silloin, kun nämä olivat esimiehen moraaliarvojen vastaisia. Moraalista rohkeutta ilmaisseet esimiehet toimivat omien arvojensa ja uskomustensa mukaisesti siitäkin huolimatta, että oma työpaikka, asema, ihmissuhteet, maine tai jopa terveys olisivat olleet uhattuina. Esimerkiksi eräs johtaja kuvasi tietoisesti poikkeavansa ylemmän tahon linjauksista, koska hän koki tietyn asiakasperheen kohdalla joustamisen olevan eettisempi ja hänen arvojensa mukainen ratkaisu: 
Sit mä sanoin, että kuule, nyt tää tehdään sitten silleen, että unohdetaanpa nuo lautakunnan linjaukset ja esimiesteni suositukset. Ja tehdäänpä nyt näin, että totta kai sinä menet siihen terapiaan, jos sinä sinne pääset ja kerrot vaan [päivähoidon] ryhmälle et millon sinne menet ja ilmoitat [tarvitsemasi] [lasten]hoitoajat. Että ilmoitapa sitten ne ja laita mulle viesti vielä pääsetkö, että mä tiedän sitten, muistan sitten. Ja sanoin, että en soittele nyt kenellekään asiakaspalvelupäällikölle enkä kenellekään, tehdään näin. (nainen, 55, työkokemusta kyseisessä tehtävässä 7 vuotta)

Sen sijaan moraalisen rohkeuden puuttuminen näytti olevan yleinen syy autenttisen päätöksentekoprosessin kesken jäämiseen. Moraalisen rohkeuden puuttuminen ilmeni esimiesten haastatteluissa esimerkiksi oman aseman tai työpaikan menettämisen pelkona:

Ja mä oon toki siinä se juridinen päätöksentekijä, että mähän oisin voinut tehdä sen [irtisanomisen], se olis se työsuhteen päättäminen astunut voimaan. Mutta tuota, sehän olis ollu suoraan esimiehen määräystä vastaan toimiminen multa. Se olisi tietysti aika oleellisesti vaikuttanut minun asemaan. (mies, 44, työkokemusta kyseisessä tehtävässä 14 vuotta)

Huomionarvoista oli, että kaikilla autenttisen päätöksentekoprosessin käytäntöön asti saattaneista esimiehistä oli taustalla pitkä työkokemus esimiehenä olemisesta omalta alaltaan. He kuvasivat kokemuksen tuoneen lisää varmuutta ja moninäkökulmaisuutta eettiseen päätöksentekoonsa. Monet näistä esimiehistä olivat sitä mieltä, että nuorempana he olivat tehneet päätöksiä nopeasti ja mustavalkoisesti, mutta kuvasivat kehittyneensä kouluttautumisen, iän karttumisen ja kokemuksista oppimisen myötä:

Mä oon sitä mieltä, että mä en ollut varmaankaan paha esimies, mut mulla on ollu sellasia nuoruuden mustavalkoisia ajattelumal- leja silloin. Mä oon varmaan ollu aika tietäväinen, et mä oon hyvinkin nopeesti varmaan [sanonut] et näin se on. Mä oon paljon dialogisempi tällä hetkellä. Et kyl se elämänkokemus ja työkokemus ja kouluttautuminen tuo paljon sellasta hyvää kyllä siihen. -- Et jotenki sillon alussa oli just tosi sääntöorientoitunut, mutta nykyisin ehkä enemmän osaa soveltaa niitä [sääntöjä] niiku maalaisjärjellisesti. Ja varmaan itessäki tapahtunu muutosta ja eri lailla kattoo taas nykyään jo asioita, mitä kymmenen vuotta sitten. (nainen, 38, työkokemusta kyseisessä tehtävässä 14 vuotta)

Lopuksi myös esimiehen omalla johtotasolla näytti olevan vaikutusta autenttisen päätöksentekoprosessin loppuunsaattamiseen. Alemman tason esimiehet eivät välttämättä aina halustaan huolimatta voineet vaikuttaa lopulliseen päätöksentekoon lain, säädösten tai ylemmiltä esimiehiltä tulevan käskyn takia. Aineistossa näkyi myös erilainen toimivalta eri aloilla, jossa toista alaa saattoivat sitoa paljon tiukemmat säädökset ja vastuu (esimerkiksi vastaava osastonhoitaja kunnallisessa terveydenhuollossa), kun taas toisen alan edustajat kokivat voivansa tehdä päätöksiä enemmän itsenäisesti (esimerkiksi yrittäjä-kauppias). Siten myös kontekstiin liittyvät tekijät vaikuttivat autenttisuuden ilmenemiseen toiminnan tasolla.

\section{Johtopäätökset}

Tässä tutkimuksessa selvitimme teoriaohjaavan sisällönanalyysin avulla, kuinka autenttisen johtajuuden osa-alueet (itsetietoisuus, läpinäkyvyys, tasapuolinen tiedonkäsittely, sisäistetty moraali; Walumba ym. 2008) ja autenttisen päätöksentekoprosessin vaiheet (eettisen ristiriidan tunnistaminen, vaihtoehtojen läpinäkyvä arviointi, aikomus toimia autenttisesti; May ym. 2003) esiintyvät esimiesten kertomuksissa eettisistä ristiriitatilanteista. Lisäksi tarkastelimme, miten autenttinen johtajuus ja autenttinen päätöksenteko kytkeytyvät toisiinsa esimiesten kertomuksissa. 
Ensimmäinen keskeinen havaintomme oli, että itsensä ja omien arvojensa läpikotainen tunteminen näyttäytyi teorian mukaisesti autenttisen johtajuuden keskeisenä lähtökohtana (Avolio ym. 2004; Avolio \& Gardner 2005; George 2003). Niiltä esimiehiltä, jotka kykenivät laajasti kuvaamaan ja reflektoimaan omia arvojaan, tunnistettiin yleensä myös muita autenttisen johtamisen ulottuvuuksia. Itsestään, vahvuuksistaan ja heikkouksistaan sekä omista arvoistaan tietoinen johtaja voi olla myös valmiimpi kehittämään omaa toimintaansa ja asettumaan toisen asemaan, mikä puolestaan lisää moninäkökulmaisuutta haastavissa tilanteissa.

Läpinäkyvyyttä, eli tilanteeseen liittyvän olennaisen tiedon ja omien todellisten ajatusten ja tunteiden jakamista muille (Walumbwa ym. 2008), esiintyi esimiesten puheessa yllättävän vähän. Vaikka osittain syyksi voitiin havaita esimiesten kuvaama eettisten tilanteiden arkaluontoisuus ja siitä johtuva salassapitovelvoite, voidaan silti pohtia, olisiko perusteltua kiinnittää huomiota avoimuuden kulttuurin edistämiseen suomalaisilla työpaikoilla. Johtajan kyky avoimuuteen voi lisätä työntekijöiden kokemuksia johtajan autenttisuudesta, minkä puolestaan tiedetään lisäävän henkilöstön motivaatioita, sitoutumista ja työtyytyväisyyttä (Avolio ym. 2004).

Tasapuolisen tiedonkäsittelyn, eli kyvyn arvioida monipuolisesti tilanteeseen liittyvää tietoa, ottaa vastaan palautetta ja halun haastaa omia näkemyksiä (Walumbwa ym. 2008), huomattiin olevan vähäisintä niillä esimiehillä, joilta puuttui luottamuksellinen suhde omaan esimieheen tai läheiseen kollegaan. Sosiaalisen tuen puuttuminen voikin heikentää johtajan kehittymistä autenttiseksi, sillä laadukkaalla sosiaalisella palautteella tiedetään olevan tärkeä rooli eettisen asiantuntijuuden kehittymisessä (Dane \& Sonenshein 2015). Sosiaalisen tuen merkityksestä päätöksenteossa olisi syytä jakaa tietoa esimiehille ja rohkaista heitä hakemaan tukea erityisesti eettisesti vaikeissa tilanteissa. Jos riittävää tukea ei ole tarjolla omassa työyhteisössä, ulko- puolinen työnohjaus tai kollegiaalinen tuki esimerkiksi erilaisissa verkostoissa ja koulutusryhmissä voi mahdollistaa vuorovaikutuksen ja näkökulmien laajentamisen.

Mayn ja kollegoiden (2003) esittämän väitteen mukaisesti sisäistetty moraali näkyi esimiesten kertomuksissa enemmän hyvinä aikomuksina kuin lopullisina tekoina. Havaintomme on linjassa aiempien eettistä päätöksentekoa koskevien tutkimushavaintojen kanssa, joiden mukaan tilanteen eettinen arviointi ei läheskään aina johda varsinaiseen eettiseen toimintaan (Blasi 1980; Treviño \& Youngblood 1990). Tässä tutkimuksessa kymmenen esimiestä kuvasi päätyneensä lopulta omien arvojensa mukaiseen ratkaisuun ja sitä seuraaviin tekoihin. Tutkimuksemme toi lisätietoa siitä, että nämä erot aikomusten ja toiminnan välillä liittyivät sekä yksilön ominaisuuksiin että ympäristön olosuhteisiin. Niitä johtajia, joiden arvot näkyivät myös toiminnan tasolla, kuvasi korkeampi johtotaso, pidempi työkokemus sekä työskentely yksityisessä organisaatiossa (vastakohtana julkinen sektori). Osa esimiehistä taas kohtasi päätöksenteossaan ympäristöstä nousevia esteitä, kuten toimivaltaa rajoittavia lakeja tai säädöksiä, tai ylemmältä taholta tulevia käskyjä, jotka rajoittivat heidän autenttista toimintaansa. Toinen autenttisuuteen vaikuttava ympäristötekijä oli omalta esimieheltä saatu tuki. Tutkittavien kokemusten mukaan tuen saaminen teki omien arvojen mukaisesta toiminnasta helpompaa.

Näyttääkin siltä, että samat tekijät, jotka lisäävät johtajan vapautta ja valtaa organisaatiossa, sekä tekijät, jotka henkilökohtaisella tasolla lisäävät johtajan voimavaroja työssä, voivat tutkimuksemme perusteella tukea myös johtajan autenttisuutta (Cooper ym. 2005). Tämän havainnon perusteella työyhteisöjen tulisi olla tietoisia siitä, että rakenteelliset esteet (esimerkiksi toimivallan tai resurssien puute) voivat estää autenttisen, moraalisen toiminnan. Johtaja voi kokea, ettei hän pysty erilaisten rajoitusten vuoksi toimimaan arvojensa mukaisesti, mikä voi puolestaan muodostaa riskin passivoitumiselle, vastuunoton 
välttämiselle tai jopa epäeettisille valinnoille. Johtajan oman autenttisuuden lisäksi onkin tärkeää kiinnittää huomiota siihen, että työympäristö ja työskentelyn olosuhteet mahdollistavat autenttisen päätöksenteon ja tukevat sitä.

Tämän lisäksi eettisen toiminnan tukemisessa näyttäisi olevan keskeistä esimiesten moraalisen rohkeuden ja moraalisuuden kyvykkyyden (May ym. 2003) tukeminen. Ne esimiehet, jotka saivat autenttisen päätöksentekoprosessin saatettua loppuun, kuvasivat kertomuksissaan moraalista rohkeutta myös silloin, kun he kohtasivat erilaisia esteitä arvojensa mukaiselle toiminnalle. He toivat esille myös työssä kertyneen kokemuksen merkitystä eettisessä päätöksenteossaan, mikä viittaa moraalisen kyvykkyyden lisääntymiseen työkokemuksen myötä. Näyttääkin siltä, että erityisesti eettisissä ristiriitatilanteissa moraalisen ulottuvuuden tiedostaminen sekä rohkeus toimia omien sisäistettyjen moraaliarvojen mukaisesti edesauttavat omien arvojen mukaista toimintaa, mikä tekee esimiesten toiminnasta autenttisempaa.

Tutkimuksemme keskeinen kontribuutio eettisen päätöksenteon tutkimuskentälle on, että autenttinen johtajuus voi tukea kehittymistä kohti vastuullista, eettisiä ratkaisuja tekevää päätöksentekoa. Johtajien kertomukset ja niiden analysointi toivat empiiristä tukea Viinamäen (2009) teoreettiselle jaottelulle, jossa on tunnistettu kolme riskitekijää eettiselle johtamiselle: ilman eettistä herkkyyttä (tässä tutkimuksessa eettisten tilanteiden tunnistamista) johtaminen on tiedostamatonta, ilman arvotietoisuutta (tässä tutkimuksessa itsetietoisuutta ja sisäistettyä moraalia) johtaminen on ajelehtivaa, ja ilman eettistä kompetenssia (tässä tutkimuksessa halua ja rohkeutta toimia autenttisesti) johtaminen epäonnistuu käytännön tasolla.

Tutkimuksemme pohjalta voidaan lopuksi todeta, että autenttinen päätöksenteko ei läheskään aina näyttäydy selkeänä kolmivaiheisena prosessina (May ym. 2003). Päätöksentekoprosessit ovat harvoin suoraviivaisia, jolloin tämänkaltaista vaiheteoriaa voi olla hankala soveltaa käytännön tilanteisiin. Tämä olikin yksi tutkimuksemme vahvuus: esimiesten omien kokemusten tarkastelu tuotti kokemusperäistä tietoa suoraan työpaikoilta, joka avaa koko organisaatiota koskevan eettisen päätöksenteon takana vaikuttavia tekijöitä. Tässä tutkimuksessa laadullisen tutkimusotteen avulla oli mahdollista kartoittaa monipuolisesti esimiesten kertomuksissa esiin tulevaa autenttisuutta ja siihen vaikuttavia tekijöitä erityisesti eettisten ristiriitatilanteiden kontekstissa, missä ilmiötä ei ole aiemmin tutkittu.

Vaikka tutkimuksen laadullisuus voidaan nähdä vahvuutena, asettaa se myös tiettyjä rajoitteita. Havaintomme pohjautuvat suhteellisen pieneen otokseen suomalaisia esimiehiä, ja siten tässä tutkimuksessa saatuja tuloksia ei voida suoraan yleistää ilman havaintojen toistamista erilaisissa ja laajemmissa aineistoissa. Erityisesti yksilöllisten tekijöiden osalta, kuten johtotason tai kokemuksen vaikutuksista autenttisuuden ilmenemiseen johtamisessa ja päätöksenteossa, voidaan tehdä vain alustavia tulkintoja tämän rajallisen tutkimusotoksen pohjalta. Lisäksi kaikki esimiehet osallistuivat tutkimukseen vapaaehtoisesti, mikä mahdollistaa sen, että joukkoon oli valikoitunut erityisesti eettisistä aihepiireistä kiinnostuneita osallistujia. Lisäksi esimiehet osallistuivat vain yhteen haastatteluun, mikä ei mahdollista autenttisuuden piirteiden tutkimista ajallisena prosessina. Vaikka esimiehet kuvasivat esimerkiksi iän ja kokemuksen tuomaa kehitystä päätöksenteossaan, nämä havainnot pohjautuivat retrospektiiviseen muisteluun. Jatkotutkimuksissa olisikin syytä selvittää tarkemmin pitkittäisasetelmaa käyttäen, miten eri autenttisuuden piirteet ja moraalinen rohkeus kehittyvät, ja onko kyse pysyvästä piirteestä vai enemmänkin dynaamisesta ilmiöstä, joka on tilanne- tai ympäristösidonnaista.

Tämän tutkimuksen perusteella autenttisuuden lisäämiseksi johtajia olisi syytä kannustaa erityisesti syvällisempään itsetutkis- 
keluun ja omia moraaliarvoja koskevaan pohdintaan. Autenttisen johtajuuden teorian pohjalta tämä voi toteutua esimerkiksi positiivisten roolimallien innostamana tai erilaisten laukaisevien tapahtumien seurauksena, jotka voivat saada johtajan aktiivisesti pyrkimään kohti syvempää ymmärrystä siitä, kuka hän on ja mitä hän arvostaa (Gardner ym. 2005). Tällöin on kuitenkin olennaista, että johtaja näkee tilanteet mahdollisuuksina kehittää itseään (Harvey ym. 2006). Lisäksi tutkimuksemme perusteella on tärkeää, että johtajat saavat sosiaalista tukea eettisesti haastavissa tilanteissa. Esimerkiksi nuoremmille johtajille erityisen hyödyllisenä voisi toimia mentorisuhde työelämässä pidempään olleisiin johtajiin, joilla on enemmän kokemusta eettisistä ristiriitatilanteista ja näin ollen mahdollisesti myös enemmän moraalista kyvykkyyttä (ks. May ym. 2003). Lisäksi esimiesvalmennuksella on mahdollista tukea johtajan autenttisuuden kehittymistä ja vahvistaa sen näkymistä myös käytännön toiminnassa.

\section{Kirjallisuus}

Avolio, B. J., Gardner, W. L., Walumbwa, F. O., Luthans, F. \& May, D. R. (2004) Unlocking the mask: A look at the process by which authentic leaders impact follower attitudes and behaviors. Leadership Quarterly 15 (6), 801-823.

https://doi.org/10.1016/j.leaqua.2004.09.003

Avolio, B. J. \& Gardner, W. L. (2005) Authentic leadership development: Getting to the root of positive forms of leadership. The Leadership Quarterly 16 (3), 315-338.

https://doi.org/10.1016/j.leaqua.2005.03.001

Barnett, T. \& Valentine, S. (2004) Issue contingencies and marketers' recognition of ethical issues, ethical judgments and behavioral intentions. Journal of Business Research 57 (4), 338-346. https://doi.org/10.1016/S01482963(02)00365-X

Blasi, A. (1980) Bridging moral cognition and moral action: A critical review of the literature. Psychological Bulletin 88 (1), 1-45.

https://doi.org/10.1037/0033-2909.88.1.1

\section{Kiitokset}

Tutkimusta on rahoittanut Suomen Akatemia (päätösnumero 294428).

\section{Kirjoittajat}

Marjut Niemi, FM, asiantuntija,

Kokkolan perheneuvola,

sähköposti: marjutniemi@gmail.com

Eveliina Vänskä, PsK, opiskelija,

Jyväskylän yliopisto, sähköposti:

eveliina.vanska@gmail.com

Mari Huhtala, PsT, dos., yliopistotutkija, Jyväskylän yliopisto, sähköposti: mari.huhtala@jyu.fi

Brown, M. E. \& Treviño, L. K. (2006) Ethical leadership: A review and future directions. The Leadership Quarterly 17 (6), 595-616.

https://doi.org/10.1016/j.leaqua.2006.10.004

Cianci, A. M., Hannah, S. T., Roberts, R. P. \& Tsakumis, G. T. (2014) The effects of authentic leadership on followers' ethical decision-making in the face of temptation: An experimental study. The Leadership Quarterly 25 (3), 581-594.

https://doi.org/10.1016/j.leaqua.2013.12.001

Cooper, C., Scandura, T. A. \& Schriesheim, C. A. (2005) Looking forward but learning from our past: Potential challenges to developing authentic leadership theory and authentic leaders. Leadership Quarterly 16 (3), 474-493.

https://doi.org/10.1016/j.leaqua.2005.03.008

Cranston, N., Ehrich, L. C. \& Kimber, M. (2006) Ethical dilemmas: The "bread and butter" of educational leaders' lives. Journal of Educational Administration 44 (2), 106-121.

https://doi.org/10.1108/09578230610652015 
Dane, E. \& Sonenshein, S. (2015) On the role of experience in ethical decision making at work: An ethical expertise perspective. Organizational Psychology Review 5 (1), 74-96.

https://doi.org/10.1177/2041386614543733

Desmet, P. T., Hoogervorst, N. \& Van Dijke, M. (2015) Prophets vs. profits: How market competition influences leaders' disciplining behavior towards ethical transgressions. The Leadership Quarterly 26 (6), 1034-1050.

https://doi.org/10.1016/j.leaqua.2015.07.004

Dinh, J. E., Lord, R. G., Gardner, W. L., Meuser, J. D., Liden, R. C. \& Hu, J. (2014) Leadership theory and research in the new millennium: Current theoretical trends and changing perspectives. The Leadership Quarterly 25 (1), 36-62.

https://doi.org/10.1016/j.leaqua.2013.11.005

Eskola, J. \& Suoranta, J. (1998) Johdatus laadulliseen tutkimukseen. Tampere: Vastapaino.

Flanagan, J. C. (1954) The critical incident technique. Psychological Bulletin 51 (4), 327-358. https://doi.org/10.1037/h0061470

Gardner, W. L., Avolio, B. J., Luthans, F., May, D. R. \& Walumbwa, F. (2005) "Can you see the real me?" A self-based model of authentic leader and follower development. The Leadership Quarterly 16 (3), 343-372.

https://doi.org/10.1016/j.leaqua.2005.03.003

Gardner, W. L., Cogliser, C. C., Davis, K. M. \& Dickens, M. P. (2011) Authentic leadership: A review of the literature and research agenda. The Leadership Quarterly 22 (6), 1120-1145. https://doi. org/10.1016/j.leaqua.2011.09.007

George, B. (2003) Authentic Leadership: Rediscovering the Secrets to Creating Lasting Value. San Francisco: Jossey-Bass.

Greenleaf, R. (1977) Servant Leadership: A Journey Into the Nature of Legitimate Power and Freatness. New York: Paulist Press.

Hannah, S. T., Avolio, B. J. \& Walumbwa, F. O. (2011) Relationships between authentic leadership, moral courage, and ethical and pro-social behaviors. Business Ethics Quarterly 21 (4), 555-578. https://doi.org/10.5840/beq201121436

Harvey, P., Martinko, M. J. \& Gardner, W. L. (2006) Promoting authentic behavior in organizations: An attributional perspective. Journal of Leadership \& Organizational Studies 12 (3), 1-11. https://doi.org/10.1177/107179190601200301
Helsingin Sanomat (1.9.2019) Postin palkitsemisjärjestelmä herättää raivoa: "Kukaan valtio-omisteisen yhtiön johtaja ei ansaitse tuollaista törkypalkkaa" [online] <URL:https://www.hs.fi/ politiikka/art-2000006224300.html>. Luettu 2.10.2019.

Hiekkataipale, M-M. \& Lämsä A-M. (2017) What should a manager like me do in a situation like this? Strategies for handling ethical problems from the viewpoint of the logic of appropriateness. Journal of Business Ethics 145 (3), 457-479. https://doi.org/10.1007/s10551-015-2911-y

Huhtala, M., Puutio, R., Lämsä, A.-M., Mauno, S., Kinnunen, U., Hyvönen, K. \& Feldt, T. (2010) Eettisesti haastavat tilanteet ja niiden kuormittavuus johtajien työssä: fokusryhmäkeskusteluiden analyysi. Työelämän tutkimus 8 (1), 13-25.

Karlsson, P-O., Aguirre, D., \& Rivera, K. (2017) Are CEOs less ethical than in the past? Strategy and Business, 87. [online]. <URL:http://www.strategy-business.com/feature/Are-CEOs-Less-EthicalThan-in-the-Past>. Luettu 8.10.2019.

Kinnunen, U., Perko, K. \& Virtanen, M. (2013) Esimiehen johtamistyylin yhteys työntekijän kokemaan työuupumukseen ja sairaana työskentelyyn. Sosiaalilääketieteellinen aikakauslehti 50 (1), 59-70.

Lemoine, G. J., Hartnell, C. A. \& Leroy, H. (2019) Taking stock of moral approaches to leadership: An integrative review of ethical, authentic, and servant leadership. Academy of Management Annals 13 (1), 148-187.

https://doi.org/10.5465/annals.2016.0121

Luthans, F. (2002) The need for and meaning of positive organizational behavior. Journal of Organizational Behavior 23 (6), 695-706.

https://doi.org/10.1002/job.165

Lämsä, A. M., Keränen, A. \& Savela, T. (2015) Vastuullinen johtajuus esimies-alaissuhteessa. Hallinnon tutkimus 34 (3), 205-218.

May, D. R., Chan, A. Y., Hodges, T. D. \& Avolio, B. J. (2003) Developing the moral component of authentic leadership. Organizational Dynamics 32 (3), 247-260.

https://doi.org/10.1016/S00902616(03)00032-9

Messick, D. M. \& Bazermann, M. H. (1996) Ethics for the 21st century: A decision making approach. MIT Sloan Management Review 37 (2), 9-22. 
Salmi, I., Perttula, J. \& Syväjärvi, A. (2014). Positiivinen näkökulma konfliktijohtamiseen: Esimiesten onnistumiset ristiriitatilanteiden ratkaisussa. Hallinnon tutkimus 33 (1), 21-38.

Sekerka, L. E. \& Bagozzi, R. P. (2007) Moral courage in the workplace: Moving to and from the desire and decision to act. Business Ethics: A European Review 16 (2), 132-149.

https://doi.org/10.1111/j.1467-

8608.2007.00484.x

Seligman, M. E. \& Csikszentmihalyi, M. (2000) Positive psychology: An introduction. The American Psychologist 55 (1), 5-14. https://doi.org/10.1037/0003-066X.55.1.5

Sinkkonen, M. \& Laulainen, S. (2010) Sosiaalialan johtajien kohtaamat eettiset ristiriidat. Janus Sosiaalipolitiikan ja sosiaalityön tutkimuksen aikakauslehti 18 (3), 225-242.

Treviño, L. K. \& Youngblood, S. A. (1990) Bad apples in bad barrels: A causal analysis of ethical decision making behavior. Journal of Applied Psychology 75 (4), 378-385.

https://doi.org/10.1037/0021-9010.75.4.378
Tuomi, J. \& Sarajärvi, A. (2018) Laadullinen tutkimus ja sisällönanalyysi (uud. laitos). Helsinki: Tammi.

Viinamäki, O. P. (2009) Eettisen johtajuuden moninaiset ulottuvuudet: Analyysissa eettisten tilanteiden tunnistaminen, arvotietoisuus ja eettinen kompetenssi. Kunnallistieteellinen aikakauskirja 37 (2), 163-175.

Walumbwa, F. O., Avolio, B. J., Gardner, W. L., Wernsing, T. S. \& Peterson, S. J. (2008) Authentic leadership: Development and validation of a theorybased measure. Journal of Management 34 (1), 89-126.

https://doi.org/10.1177/0149206307308913

Weaver, G. R. (2006) Virtue in organizations: Moral identity as a foundation for moral agency. Organization Studies 27 (3), 341-368.

https://doi.org/10.1177/0170840606062426 


\section{ENGLISH SUMMTARY}

Marjut Niemi, Eveliina Vänskä \& Mari Huhtala

\section{How does authenticity manifest in leaders' ethical decision-making?}

Authentic leadership is a positive leadership style that builds on knowing oneself and aims towards being true to oneself. Authentic decision-making highlights ethical motives for actions that are aligned with personal values. This study investigated if authentic leadership and the authentic decision-making process can be identified from managers' personal experiences of facing ethical dilemmas. We studied 25 managers who worked in both public and private organisations, at different leadership levels, and in different employment fields. The data were collected with semi-structured interviews and analysed using theory-driven content analysis. The results showed that components of authentic leadership (self-awareness, relational transparency, balanced processing of information, and an internalized moral per- spective) and the authentic decision-making process (recognising ethical dilemmas, transparent evaluation of alternatives, and intentions to act authentically) were identified in the managers' ethical decisions. However, less than half of the managers converted their intentions into actions that showed alignment with their personal values. Whether or not the manager acted on their intentions related to both individual and contextual factors. Thus, we can conclude that authenticity in ethical decision-making is more likely to take place when managers' personal attributes (e.g. work experience and self-reflection abilities) and workplace conditions (e.g. social relationships) support the managers' autonomy, capacity, and courage to act according to their values. 